Design and Function of Lowe and Sawmill Points from the Preceramic Period of Belize

Stemp, W. James; Awe, Jaime J.; M. Prufer, Keith M.; Helmke, Christophe

Published in:

Latin American Antiquity

DOI:

$10.7183 / 1045-6635.27 .3 .279$

Publication date:

2016

Document license:

Unspecified

Citation for published version (APA):

Stemp, W. J., Awe, J. J., M. Prufer, K. M., \& Helmke, C. (2016). Design and Function of Lowe and Sawmill Points from the Preceramic Period of Belize. Latin American Antiquity, 27(3), 279-299.

https://doi.org/10.7183/1045-6635.27.3.279 


\title{
DESIGN AND FUNCTION OF LOWE AND SAWMILL POINTS FROM THE PRECERAMIC PERIOD OF BELIZE
}

\author{
W. James Stemp, Jaime J. Awe, Keith M. Prufer, and Christophe G.B. Helmke
}

\begin{abstract}
To date, 81 stemmed and barbed preceramic (Archaic) points (8000-900 B.C.) have been identified in Belize. Fifty-four are Lowe points; 21 are Sawmill points. Four more are provisionally classified as Allspice and two as Ya'axche' points. These stemmed bifaces are frequently beveled on alternate-opposite edges and demonstrate variable degrees of resharpening and reworking, which affects blade shape and tool size. Numerous functions have been attributed to these artifacts; specifically, they have been called spear points, dart points, harpoons, and knives. Metric data from these bifaces, limited macrowear and microwear analyses, and design features, such as barbs and alternate-opposite edge beveling, have been used to interpret likely tool functions. Results suggest that Lowe points were affixed to throwing/thrusting spears and also served as knives, whereas the Sawmill points were used as spear-thrower dart points and as knives. New dating information suggests that alternate-opposite edge beveling and consequently beveled bifaces may be much older than 2500-1900 B.C., which is the date currently assigned to these specimens.
\end{abstract}

Hasta la fecha, 81 puntas pre-cerámicas (Arcaico) (8000-900 a.C.) pedunculadas y con aletas han sido descubiertas a lo largo de Belice. Cincuentaicuatro han sido identificadas como puntas de tipo Lowe, 21 como puntas Sawmill y seis han sido clasificadas de manera provisional, de las cuales cuatro son Allspice y dos Ya'axche'. Estos bifaces pedunculados están frecuentemente biselados sobre los bordes alternos-opuestos y muestran grados variables de retoques y reavivamiento, lo cual afecta tanto la forma de la lámina como el tamaño del instrumento. Se han atribuido numerosas funciones a estos artefactos, específicamente como puntas de lanza, puntas de dardo, arpones y cuchillos. Los datos métricos de estos bifaces, el análisis limitado de las macro y microhuellas de uso y las características del diseño tales como las aletas y el biselado alterno-opuesto, se han utilizado para interpretar las posibles funciones de estas herramientas. Los resultados sugieren que las puntas de Lowe fueron enmangadas en lanzas arrojadizas y también sirvieron como cuchillos, mientras que las puntas Sawmill fueron utilizadas como puntas de dardo en propulsores, así como también como cuchillos. La nueva información acerca de la cronología sugiere que el biselado del borde alterno-opuesto y consecuentemente los bifaces biselados podrían ser mucho más antiguos que 25001900 a.C., fecha actualmente asignada a estos especímenes.

$\mathrm{T}$ There has been renewed interest in the Preceramic period of Belize since the significant work of archaeologists in the 1980s and 1990s (Hester et al. 1980a, 1980b, 1981, 1996; Iceland 1997; Kelly 1993; Pearson and Bostrom 1998; Pohl et al. 1996; Zeitlin 1984; Zeitlin and Zeitlin 2000; see MacNeish 1981, 1982, 1983; MacNeish and Nelken-Terner 1983a, 1983b; Mac-
Neish et al. 1980). This is primarily due to the fact that the quantity of evidence for a Paleoindian and Archaic period presence in Belize has increased in recent years based on the recovery of Pleistocene faunal remains and lithics from a number of locations throughout the country (e.g., Aylesworth et al. 2011; Helmke and Ishihara 2001; Lohse and Collins 2004; Lucero et al. 2011;

W. James Stemp — Department of Sociology, Anthropology and Criminology, Keene State College, Keene, NH, 034353400,USA (jstemp@keene.edu)

Jaime J. Awe $\square$ Department of Anthropology, Northern Arizona University, Flagstaff, AZ, 86011-5200, USA (jaime.awe@nau.edu)

Keith M. Prufer - Department of Anthropology, University of New Mexico, Albuquerque, NM, 87131, USA (kmp@unm.edu)

Christophe G.B. Helmke $\square$ Institute of Cross-cultural and Regional Studies, University of Copenhagen, Karen Blixens Vej 4, DK-2300 Copenhagen S, Denmark (cgbh@hum.ku.dk) 
Rosenswig 2004, 2015; Rosenswig and Masson 2001; Rosenswig et al. 2014; Stemp and Awe 2013; Stemp et al. 2016). In particular, additional stemmed and barbed bifaces have been recovered that conform to the technological and stylistic criteria of two types of points: Lowe and Sawmill. These have been considered Late Archaic (ca. 2500-1900 B.C.) in date (Iceland 1997; Kelly 1993; Lohse 2010; Lohse et al. 2006). Nevertheless, the function and chronology of these tools remains unclear. Lowe points have been variously referred to as knife blades, thrusting spear points, projectile/dart points, and harpoon heads (e.g., Clark and Cheetham 2002; Hester et al. 1980a; Iceland and Hester 2001; Kelly 1993; Lohse 2010; Lohse et al. 2006; MacNeish and Nelken-Terner 1983a; MacNeish et al. 1980; Rosenswig 2015; Stemp and Awe 2013; Valdez and Aylesworth 2005). The proposed functions of Sawmill points have included dart points and knives (Kelly 1993; Lohse 2010; Stemp and Awe 2013). Tool function is addressed in this paper by analyzing tool morphology, metric data, and limited macrowear and microwear evidence derived from the largest sample of documented Lowe and Sawmill points discovered in modern-day Belize. These data are compared to ethnographic, ethnological, and experimental tools with known functions, as well as other archaeological evidence.

\section{Chipped Stone Points in Archaic Mesoamerica}

Although our study focuses on point types identified in what is traditionally known as the Late Archaic period of Belize, hunter-gatherers in other regions of Mesoamerica produced similar varieties of stemmed and barbed bifaces in the Preceramic period. Therefore, it is worthwhile briefly commenting on sites with diagnostic Archaic chipped stone points in these regions.

\section{Mexico}

MacNeish et al. (1967) established one of the first preceramic lithic typologies in Mesoamerica based on excavations in the Tehuacan Valley. Projectile point types, including Coxcatlan, Hidalgo, Lerma, Pedernales, and Tortugas, were used as chronological markers to date levels and the timing of occupations at various sites. Hardy (1996) has since performed a reanalysis of a small percentage of the thousands of lithics recovered from the Tehuacan Valley and found significant flaws with the original analysis and subsequent typology.

In the Valley of Oaxaca, Flannery (1986) reconstructed Early Archaic life based on excavations at Guila Naquitz Cave. He recovered an assemblage of 1,716 flakes, bifacial choppers, macroflake tools, and bifaces, including Lerma and Trinidad points, as well as two Pedernales points (Hole 1986). Evidence of Archaic-period occupation in this valley also was discovered at Cueva Blanca and Gheo-Shih. In terms of lithic technology, many projectile points of the Coxcatlan, Hidalgo, La Mina, San Nicolas, Tilapa, and Trinidad types were identified at Gheo-Shih (Flannery and Spores 1983). At Cueva Blanca, Archaic-period levels also yielded point types like those from the Tehuacan Valley, including La Mina, San Nicolas, Trinidad, and Pedernales (Flannery and Spores 1983). The rhyolite Xaagá biface fragment is another example of a "Pedernales"-like Archaic point from Oaxaca (Winter 2007:196-197, Figure 9.3).

In the Central Balsas region of Guerrero, archaeologists working in the Xihuatoxtla rockshelter recovered modified river cobbles and other chipped stone tools and debitage in levels radiocarbon dated to the Archaic period. They also found a stemmed, indented base point fragment that they called Pedernales based on its similarity to Pedernales points from Guila Naquitz in Oaxaca and the Tehuacan Valley (Ranere et al. 2009:5017, Figure 5A). Perttula (2009:73) noted that this point came from a layer that is "at least 5,000 to 6,000 years older than the known age of Pedernales points from Texas" and should be given a different type name based on location of recovery and associated time period.

In Michoacan, Archaic period occupation was documented in Cueva de los Portales. At different levels within the cave, there are flaked tools made from andesite and obsidian. Tools include heavy choppers, scrapers, gravers, blades, and numerous stemmed point types, such as San Nicolas, Gary, Abasolo, Nogales, La Mina, Tortugas, and Pedernales (Faugère 2006).

Along the Pacific coast of the Isthmus of Tehuantepec, Oaxaca, lithic evidence associated with the Archaic period, specifically a shortstemmed, basally notched, Pedernales-like point 
made from gray rhyolite, was discovered at the site of Barrio Tepalcate (Winter 2007:196-197, Figure 9.3).

\section{Guatemala}

Los Tapiales, a Paleoindian campsite, also contained a significant Archaic-period component. In addition to the fluted-point base fragment and a "fluting" flake, there was an assemblage of roughly 1,400 chipped stone artifacts, mostly consisting of basalt, obsidian, and chalcedony flake tools, as well as 14 biface fragments and a unifacial obsidian point (Gruhn and Bryan 1977).

From surface finds, Brown (1980) identified Palaeoindian and Archaic-period sites in the Guatemalan highlands based on two Palaeoindian points and nine Archaic-period points, including Lerma, El Riego, Flacco, and Abasolo, The identification of the Archaic-period points was based on similarities with the types recognized by MacNeish in the Tehuacan Valley (Brown 1980:317318 , Figure 4).

\section{Honduras}

Scheffler's $(2008,2012)$ work in the El Gigante Rockshelter provides solid evidence for early preceramic occupation with a series of radiocarbon dates extending back to the Palaeoindian period. Also recovered from the rockshelter were projectile points from levels that were dated to the Early Archaic that he describes as stylistically similar to the Pedernales type (Scheffler et al. 2012:603).

\section{Belize}

In addition to the Tehuacan Valley, MacNeish and Nelken-Terner (1983a, 1983b) excavated sites in northern Belize and developed a preceramic lithic typology there as well. Their stone tool sequence, with some revision, included six phases or complexes (Lowe-ha, Sand Hill, Orange Walk, Belize, Melinda, and Progreso) that extended from about 9000-2000 B.C. and included point forms termed "Lerma-like," "Pedernales-like," and "Shumlalike," among others. Nevertheless, this analysis and categorization of the diagnostic tool types in northern Belize suffered from some of the same problems as the Tehuacan Valley typology (see Hester 1986:413). Given these issues and the subsequent work of Hester et al. (1980a, 1980b, 1995,
1996), Kelly (1993), and Iceland (1997, 2005), these phases, as well as the point type designations, are no longer considered valid.

\section{Preceramic Points from Belize}

In Belize, there are only seven confirmed points (Lohse 2006:214-216) from the Paleoindian period (ca. 11,000-8000 B.C.) and one possible point (Stemp et al. 2016) from the Paleoindian/Early Archaic (ca. 8000-6000 B.C.). In contrast, there is abundant evidence of Late Archaic (3400-900 B.C.) stone tool technology. In terms of bifacial points, Lowe and Sawmill are the two main types from this time period, although there may be some sub-variation in the Lowe type (see Stemp and Awe 2013:24, 26). A third provisional category of Allspice points has been suggested by Kelly (1993:216), and we propose a fourth provisional point type named Ya'axche'. In this paper, we present quantitative and qualitative data for 54 Lowe, 21 Sawmill, four Allspice, and two Ya'axche' points recovered throughout Belize (Figure 1, Table 1, Supplemental Tables 1-4).

Most of the preceramic points from Belize are made from chert that is heavily to completely patinated. Both off-white/yellowish and hard white patinas have been associated with points recovered in northern Belize. Nearly all of the less patinated bifaces were made from chert from the "chertbearing zone" [CBZ] of northern Belize (see Lohse 2010; Lohse et al. 2006; Stemp and Awe 2013). The Lowe point from Pulltrouser Swamp was made from chalcedony (Iceland 1997:194).

\section{Lowe Points}

Lowe points (Figure 2) are "characterized by broad shoulders, often with sharply defined barbs; wide stems that are square or slightly expanding; and, occasionally, sub-parallel oblique flaking on their blades" (Lohse et al. 2006:217). Typically, their wide, straight-sided stems are ground along the edges from barb tip to barb tip (Kelly 1993:210). The barb angles on most Lowe points are between $45^{\circ}-65^{\circ}$ (Kelly 1993:210; Stemp and Awe 2013:20, Table 1). They often possess pronounced alternate-opposite beveling on left edges and an off-white patina with a yellowish stain (Kelly 1993:210). 


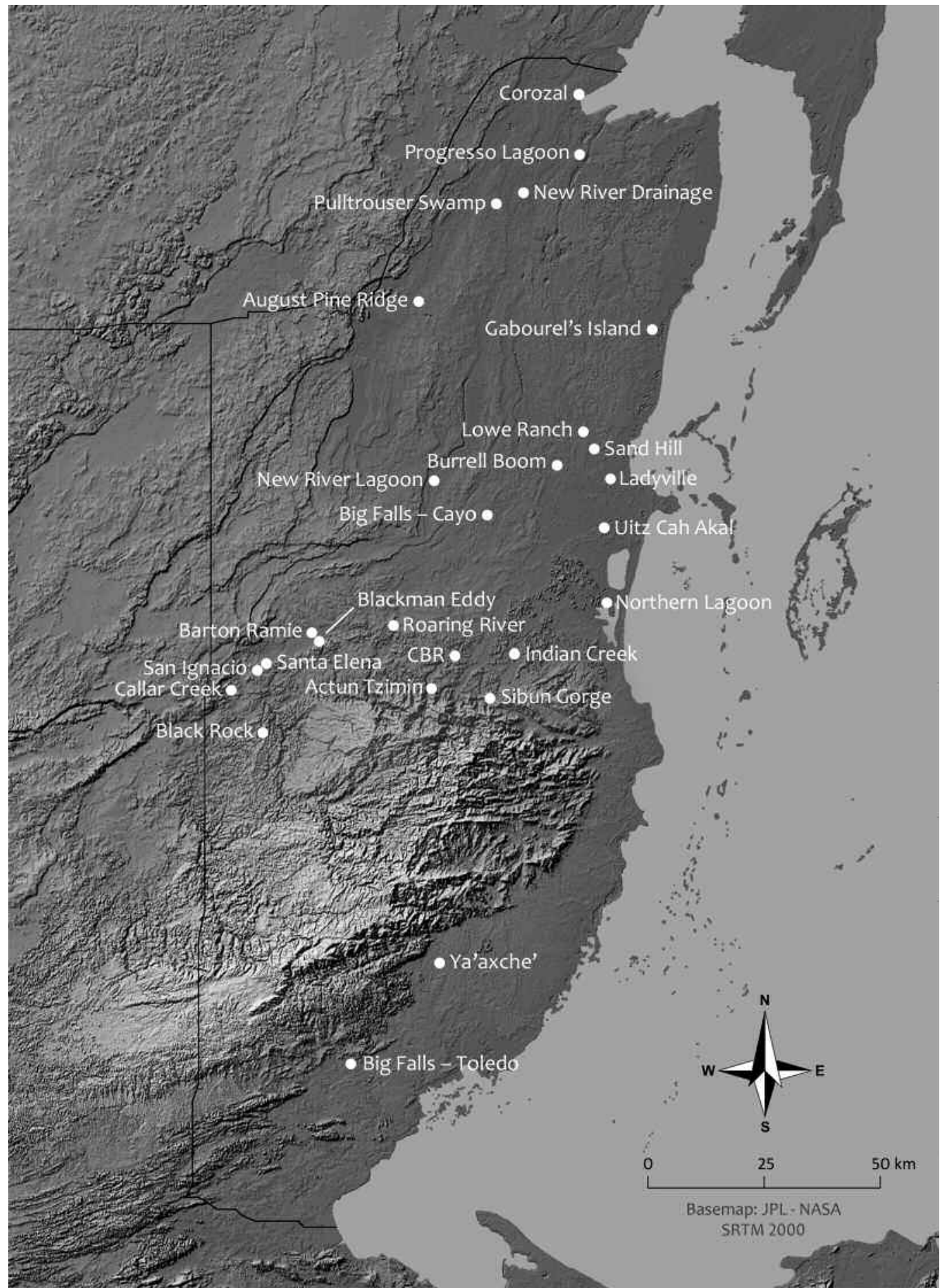

Figure 1. Locations in Belize where Lowe, Sawmill, Allspice, and Ya'axche' points have been found (map by C. Helmke). 


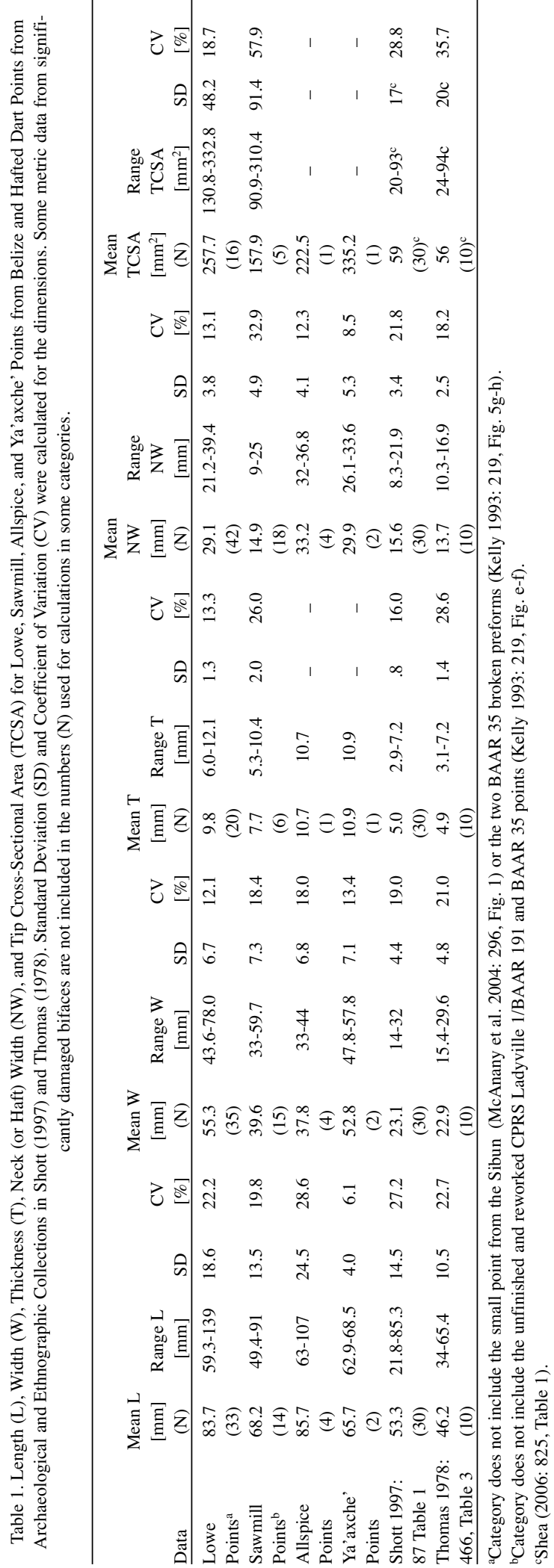



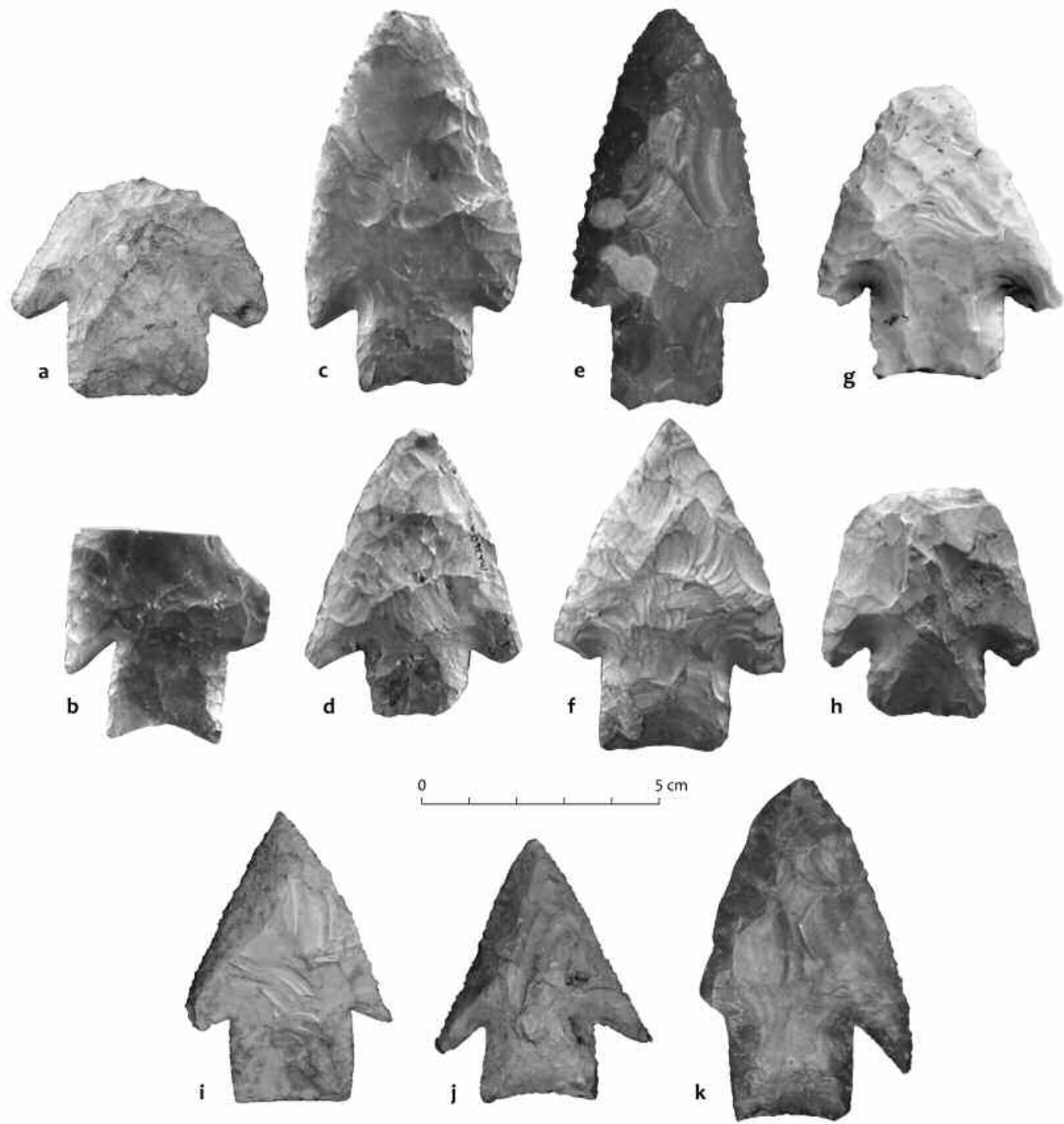

Figure 2. Selection of Lowe points: (a) point found under the Hawksworth Bridge, San Ignacio; (b) point JuaD/98/12/2 found near Ladyville; (c) point JuaD/98/12/4 found near Ladyville (also see Figure 7b); (d) unprovenanced point (PNK 360) (also see Figure 7a); (e) point found in a rockshelter near Indian Creek, in western Belize; (f) unprovenanced point (PNK 1268); (g) Point found at Blackman Eddy; (h) unprovenanced point; (i) point SB-BF-1 from Big Falls, Toledo District; (j) point SB-BF-2 from Big Falls, Toledo District; (k) point SB-BF-3 from Big Falls, Toledo District (photographs by J. Awe, K. Prufer and W. J. Stemp).

\section{Sawmill Points}

Sawmill points (Figure 3a-d) are "somewhat narrower and appear more delicately flaked than Lowe points" and "are characterized by fine parallel-oblique pressure flaking, occasionally trending into a beveled blade, sharp barbs defined by deep basal or corner notches, and have expanding stems that sometimes retain a false flute" (Lohse et al. 2006:217). The barb angles for these points are generally narrower than those on the larger Lowe points (Kelly 1993:216; Stemp and Awe 2013:20-21, Table 1), with most ranging between $30^{\circ}-45^{\circ}$. The edge beveling on the Sawmill points is similar to that described for the Lowe points. Sawmill points usually developed a "very hard, white patina" (Kelly 1993:216). 
a
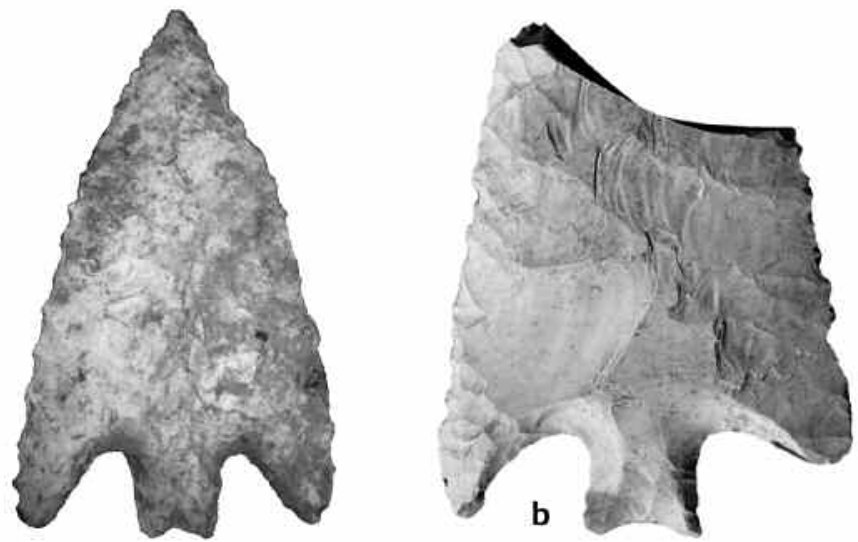

c
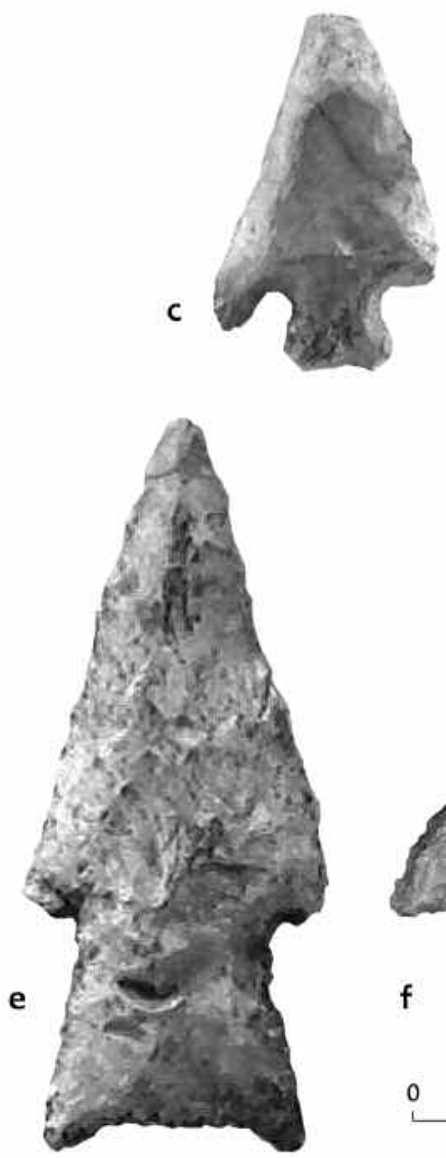

d
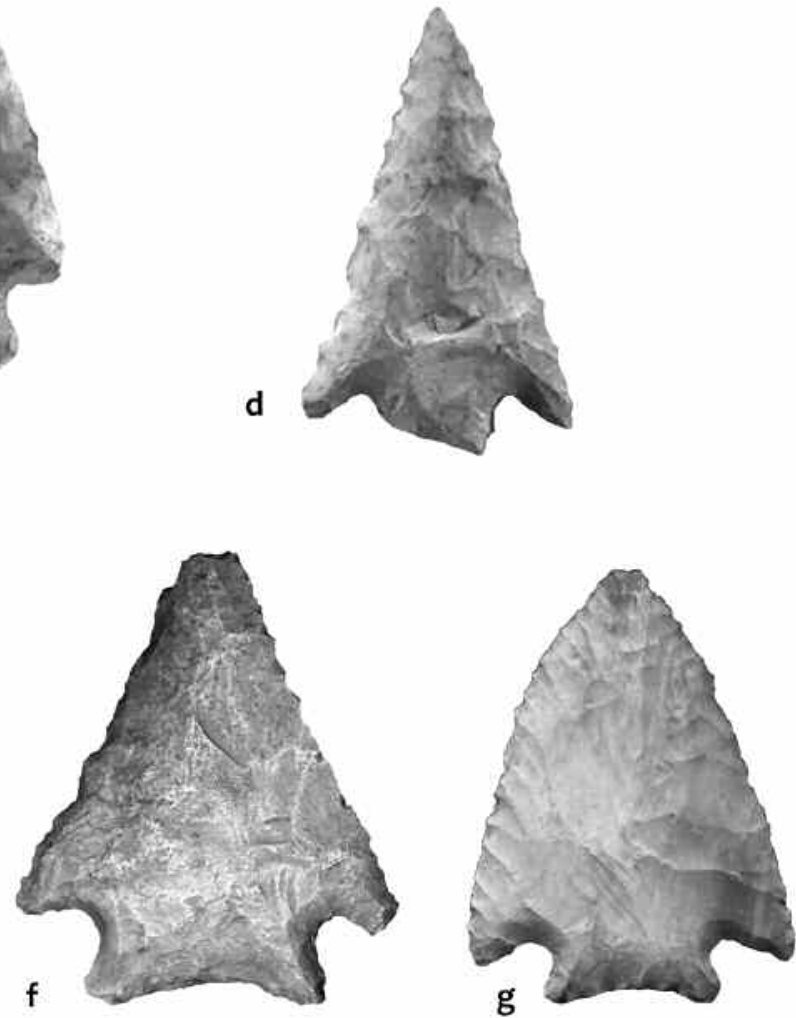

0

$5 \mathrm{~cm}$

Figure 3. (a) Sawmill point in a private collection from Corozal, northern Belize. (b) Sawmill point found on the west bank of the Mopan River in Callar Creek village. (c) Sawmill point RTI 18. (d) Sawmill point RTI 13. (e) Provisional Allspice point (RTI 64) from the Sibun River Valley, Cayo District. (f) Provisional Ya'axche' point found on land managed by the Ya'axché Conservation Trust. (g) Provisional Ya'axche' point from the Bladen Nature Reserve, southern Belize (photographs by J. Awe, M. Caal, L. McLoughlin and W. J. Stemp). 


\section{Allspice Points}

Although few Allspice points have been identified, there is some morphometric standardization to these artifacts. Allspice points are long, somewhat narrow points with short barbs and long expanding stems with variable degrees of basal thinning (Figure $3 \mathrm{e})$. Stem bases are either flat or concave, and stem edges are ground like other preceramic points. These points also possess alternate-opposite edge beveling. The points have the same heavy whitish-yellow patina as Lowe points (Kelly 1993:216). Based on the damage to the barbs on three of the Allspice points, reliable measurements of barb angles are not possible.

\section{Ya'axche' Points}

Stemp and Awe (2013:28) posited that a point recovered from the Bladen Nature Reserve was a new type based on the style and dimensions of its stem. Following the recent discovery of a second point with a similar stem, we propose a new provisional type called Ya'axche' in recognition of the gentlemen who found them-Mr. Lee McLoughlin and Mr. Maximiliano Caal from the Ya' axché Conservation Trust. Both points possess a short, wide, and expanding "eared" stem with a basal concavity. Point stems are basally thinned on both faces but not fluted. This stem style is somewhat similar to those on points from El Gigante, Honduras (see above). The shapes of the blades differ due to the alternate-opposite edge beveling on one of them (Figure 3f) and minor edge resharpening on one edge of the second (Figure 3g). The barb angles of the points measure $45^{\circ}-55^{\circ}$. Both of these artifacts are heavily patinated.

\section{Dating of Preceramic Points from Belize}

Although most of these bifaces are surface finds, there are three associated radiocarbon dates reported (2500-1900 cal B.C.) for Lowe points (Kelly 1993:215; Pohl et al. 1996:363, Table 1). Points without associated radiocarbon dates, including Sawmill and Allspice, have been assigned to the Late Archaic period based on stylistic and technological similarities to the Lowe points, including stems, barbs, and corner-notching. Late Archaic points are frequently resharpened using an alternate-opposite edge beveling technique that has not been reported on any Paleoindian point
(Lohse et al. 2006) or Preclassic, Classic, or Postclassic Maya (ca. 1200 B.C.-A.D. 1500) biface from Belize (Hester 1985).

The current dating of beveled points from Belize may require rethinking because Keith Prufer's project recently recovered a point/knife fragment with alternate-opposite edge beveling in the Toledo District of Southern Belize from a context associated with two radiocarbon dates spanning 10,200-10,500 B.P. (Figure 4a). Despite the lack of a diagnostic base/stem on this point fragment, this discovery suggests that this type of beveling may have appeared earlier than currently thought in Belize. By way of comparison, alternate-opposite edge beveling on North American points is introduced in the Late Paleoindian-Early Archaic period on Dalton points (8500-7500 B.C.). Other Early Archaic points, including Hardaway-Dalton (8000-7000 B.C.), Hardin Barbed (8000-5500 B.C.), and Thebes points (8000-6000 B.C.), are also resharpened using this technique (Goodyear 1982; Justice 1995). In southern Texas and northern Mexico, alternate-opposite edge beveled lanceolate Lerma points and stemmed Bandy (Martindale), Bulverde, and Abasolo points date from the Early to Middle Archaic period (ca. 8000-3000 B.C.; Turner et al. 2011). The early date for the biface fragment with alternate-opposite edge beveling from southern Belize also raises questions concerning the gap in the current point chronology of that country from roughly 9000 to 2500 B.C.

Although Sawmill points have been suggested as examples of Late Archaic technology, no radiocarbon dates are currently associated with them. Kelly (1993:216) suggested they were younger than the Lowe and Allspice points based on their degree of patination. Given the early date associated with the beveled tool from southern Belize, we will break with tradition and refer to Lowe, Sawmill, Allspice, and Ya'axche' points simply as "preceramic" throughout the rest of this paper.

\section{Preceramic Biface Function: Metric Analysis}

To determine the functions of preceramic bifaces from Belize, we performed metric analyses for comparison with hafted stone points in archaeological and ethnographic collections from North and South America and Australia (Shea 2006; Shott 

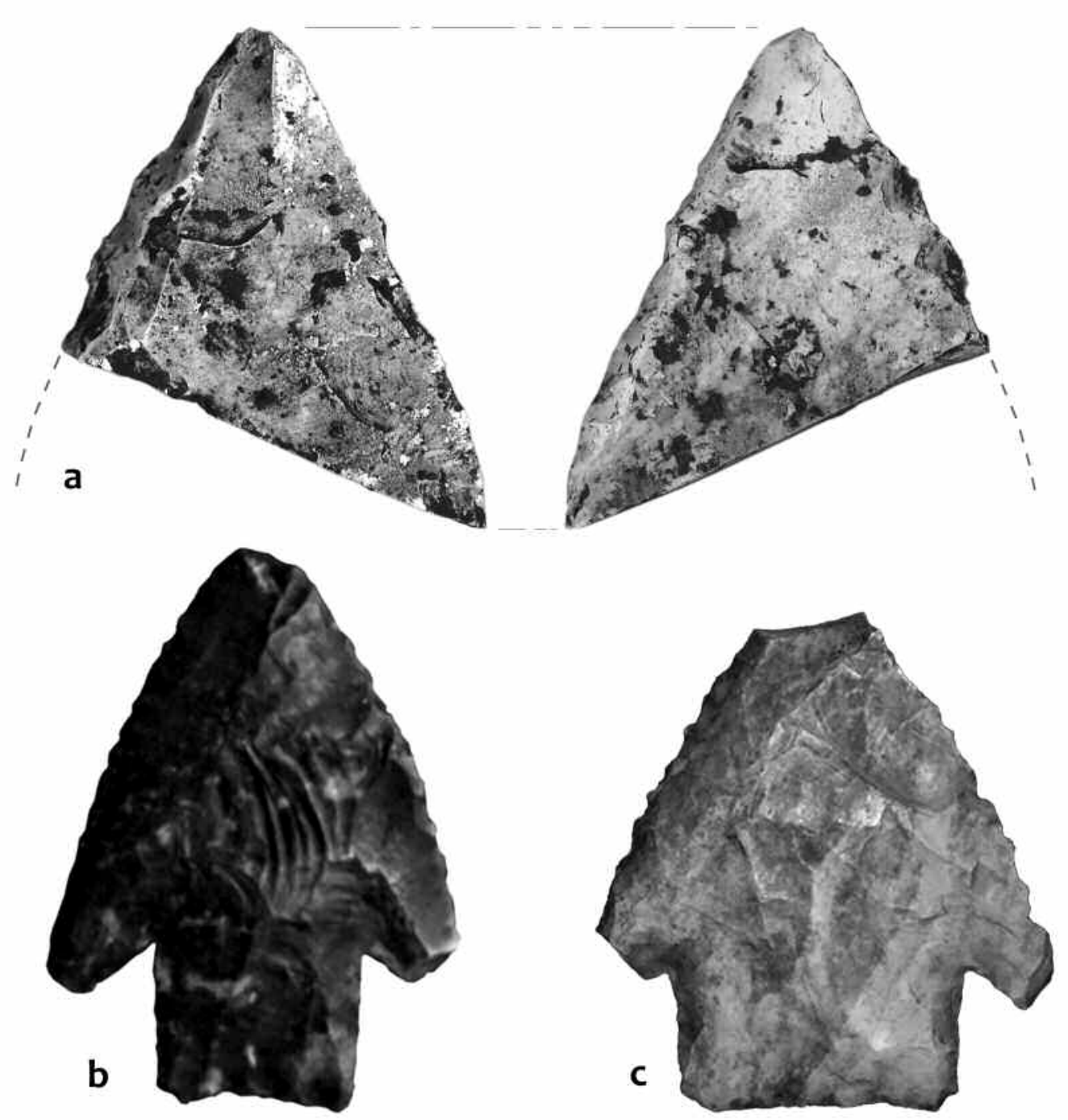

0

$5 \mathrm{~cm}$

Figure 4. (a) Two views of a beveled point/knife fragment from the Toledo District of Southern Belize. Photographs of projectile damage. (b) The Lowe point discovered by Ada Awe Wood with a cone-like fracture of the distal end. (c) The Black Rock 1 point with a hinge-terminating bending fracture of the distal end (photographs by J. Awe and K. Prufer).

1997; Thomas 1978). Only the Lowe and Sawmill points were included in this part of the analysis, based on sample sizes. We chose size rather than mass for metric analysis primarily due to the absence of published weights for many of the points included in this study and the fact that we could not weigh the points held in private collections.

Biface preforms, such as the Lowe point stems from Northern Belize (Kelly 1993:219, Figure 10g, h), were not included in any of the metric analyses. Artifacts that were significantly damaged, such as the blades of the two Lowe points from Uitz Cah Akal (Lohse 2010:329, Figure 8), were included in only some of the metric analyses. Moreover, measurements (primarily length and width) from points that were substantially reduced in size due to resharpening or other reworking, such as the Lowe point from Sibun (McAnany 2010:31, Figure 
2.3; McAnany et al. 2004:296, Figure 1), were omitted from calculations in Table 1.

\section{Maximum Length, Width,}

Thickness, and Neck Width

Lowe and Sawmill points differ in terms of both overall length and width. For those that are whole or almost whole, the mean maximum length and width for Lowe points are $83.6 \mathrm{~mm}$ and $55.3 \mathrm{~mm}$, whereas Sawmill points average $68.3 \mathrm{~mm}$ long and $39.6 \mathrm{~mm}$ wide. The least damaged and reworked/resharpened Lowe point is the JuaD/98/12/4 specimen, which is $96.5 \mathrm{~mm}$ long and $55.2 \mathrm{~mm}$ wide. The Actun Tzimin point, which measures $63.6 \mathrm{~mm}$ long and $33.1 \mathrm{~mm}$ wide, is the least modified whole Sawmill point. Neither point is the largest of its type. Both points are excurvate in outline, which suggests that this is likely the original shape of Lowe and Sawmill points. One of the excurvate point fragments without beveling from Uitz Cah Akal confirms this.

Lowe points are quite long (Table 1; Figure 5a) when compared to examples in Thomas (1978) and Shott (1997). Nonetheless, the lengths of many Sawmill points overlap with those of the Thomas (1978) and Shott (1997) hafted dart points, specifically within the $45-85 \mathrm{~mm}$ range. In this range, there is no statistically significant difference in the lengths between the Sawmill vs. Thomas (1978) points $(t=1.9668, d f=10, p<$ $0.05)$ or Sawmill vs. Shott (1997) points $(t=$ $1.7119, d f=21, p<0.05)$ based on Welch's t-test. When all lengths are included, the differences between the Sawmill vs. Thomas (1978) points $(t=$ 4.4867, $d f=21, p<0.05)$ and Sawmill vs. Shott (1997) points $(t=3.3296, d f=27, p<0.05)$ are significant. Nevertheless, Cundy (1989) and Hutchings (1997) demonstrate that dart points can vary in terms of their lengths and widths and that some dart tips are quite large. Some Australian aborigine javelins are tipped with long and narrow stone, bone, and metal points (Cundy 1989:109111, Figure 28; Newman and Moore 2013:2615, Figure 1, 2616:Figures 2-3).

In terms of the maximum widths, the Lowe and Sawmill points are significantly different from the hafted dart points in Table 1. Lowe points are substantially wider than the hafted dart points, whereas the Sawmill points tend to overlap to a minimal degree with the Thomas (1978) and Shott
(1997) points (Figure 5b). One important functional aspect related to the width of points concerns depth of penetration. Wide points may not penetrate as deeply as narrow ones, although force upon impact undoubtedly affects this relationship (see Hrdlicka 2003; Whittaker 2010).

Measurements of biface thickness indicate that the Lowe points are much thicker than the hafted archaeological examples (Shott 1997; Thomas 1978). Although the mean thickness of the Sawmill points is less than that of the Lowe points, the Sawmill points are still thicker than the Thomas $(t=3.0146 ; d f=7 ; p<0.05)$ and Shott $(t$ $=3.2551 ; d f=5 ; p<0.05)$ points. Neither point type would be classed as a dart based on these data.

Neck width may be the most important criterion for determining the function of a biface used as a projectile because the width of the neck/stem is related to the diameter of the foreshaft/shaft of the projectile. When comparing the data for maximum neck width for the hafted specimens (Table 1, Figure 6a), the Sawmill points overlap significantly, but the Lowe points do not. There is no significant difference in neck widths between the Sawmill and Thomas (1978) points $(t=0.8574, d f=25, p$ $<0.05)$ or Shott (1997) points $(t=0.3396, d f=26$, $p<0.05)$. Neck width supports the suggestion that Sawmill points could have served as dart points.

Corliss (1972:Table 1) provides some additional support for Sawmill points as darts based on neck widths that ranged from $0.93 \mathrm{~cm}$ to 1.28 $\mathrm{cm}$. Yet many dart point neck widths in his Figures 4-7 exceeded $1.50 \mathrm{~cm}$, and he omitted some examples with necks that were wider (Corliss 1972:14). Hutchings (1997:73) provided a wider range for foreshaft diameters from North American spear-throwers $(0.6-1.9 \mathrm{~cm})$, and experiments involving the use of Clovis points on elephants by Frison (1989:769, Table 2) included larger foreshaft diameters (13.9-22.2 mm). In contrast, mean haft/foreshaft diameters of $20 \mathrm{~mm}$ (Shea 2006:823-824), 22 mm (Huckell 1982:219, Table 1), $23 \mathrm{~mm}$ (Hughes 1998:355, Table III), and 24$25 \mathrm{~mm}$ (Gramly 1984:113) have been suggested for thrusting spears, which may provide support for the use of some $(N=7,16.7$ percent) Lowe points as throwing/thrusting spear tips.

In addition to the metric analyses using the individual Lowe and Sawmill point dimensions 

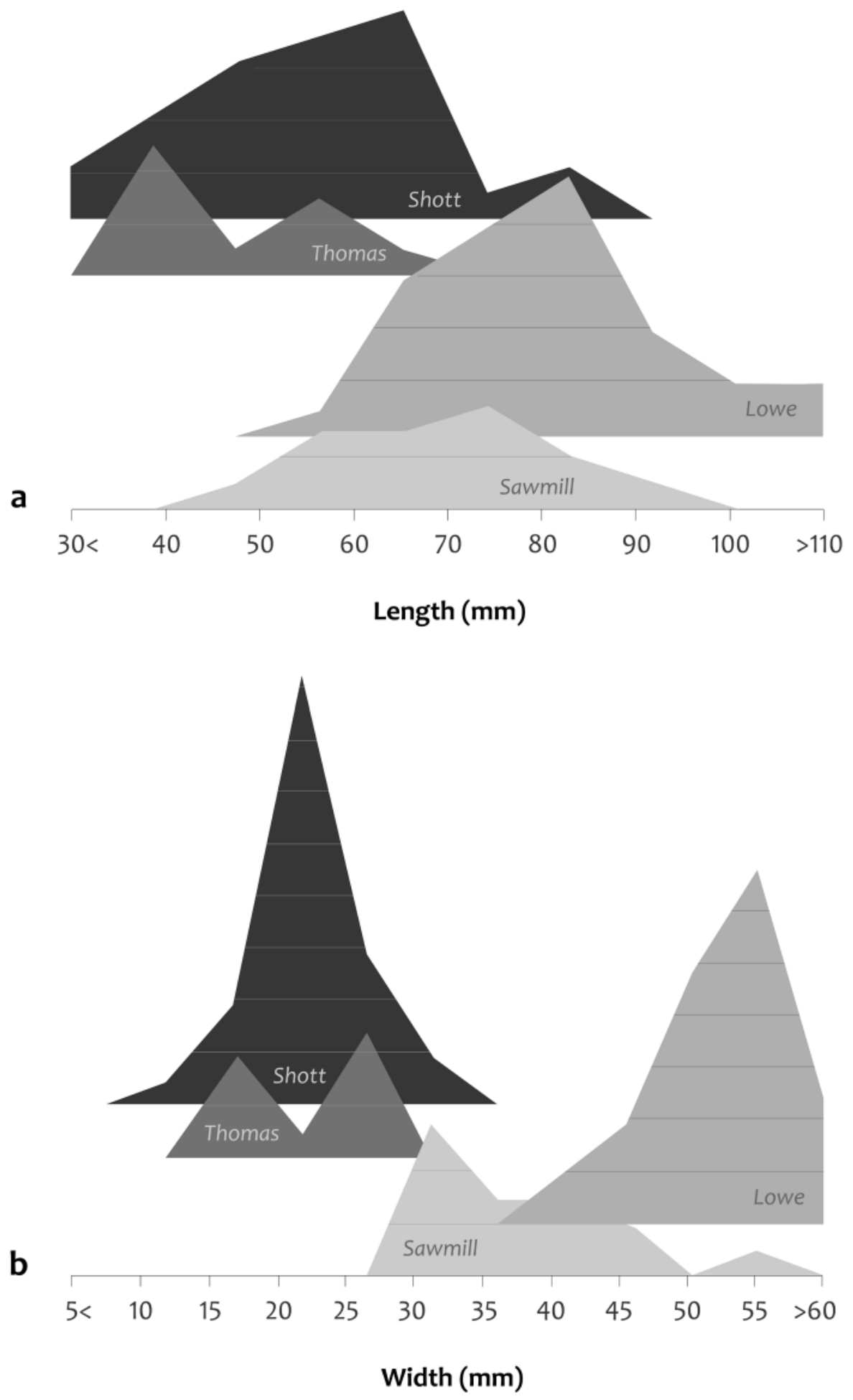

Figure 5. Absolute frequency distribution of Lowe, Sawmill, and archaeological and ethnographic dart points in Shott 1997 and Thomas 1978 by: (a) length $(\mathrm{mm})$ and $(\mathrm{b})$ width $(\mathrm{mm})$. Note that individual curves are unstacked and that the gridlines represent increments of two in absolute frequency (charts by C. Helmke and W. J. Stemp). 


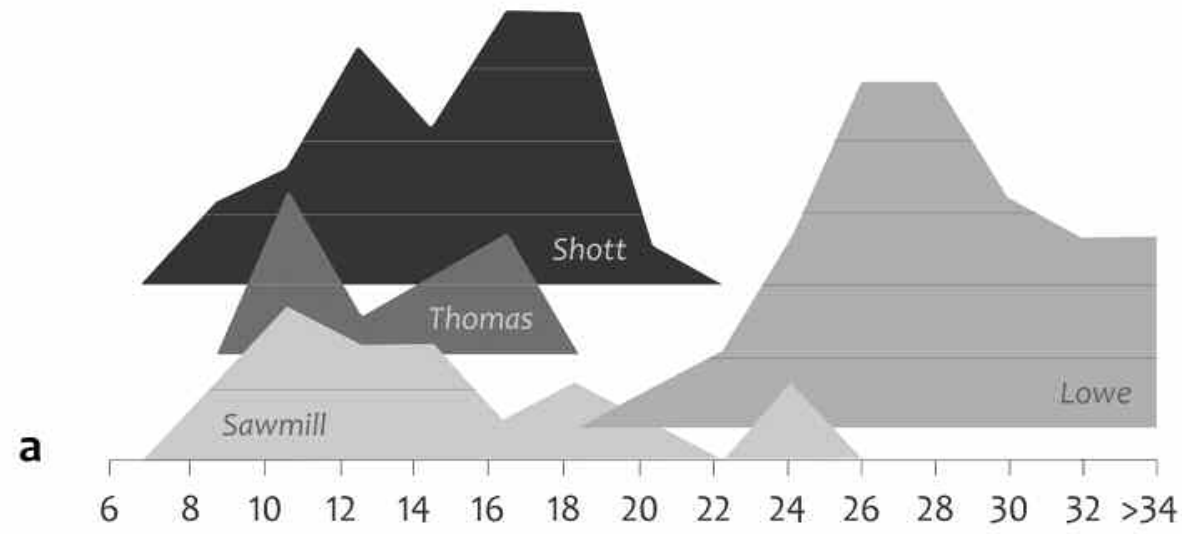

Neck Width (mm)

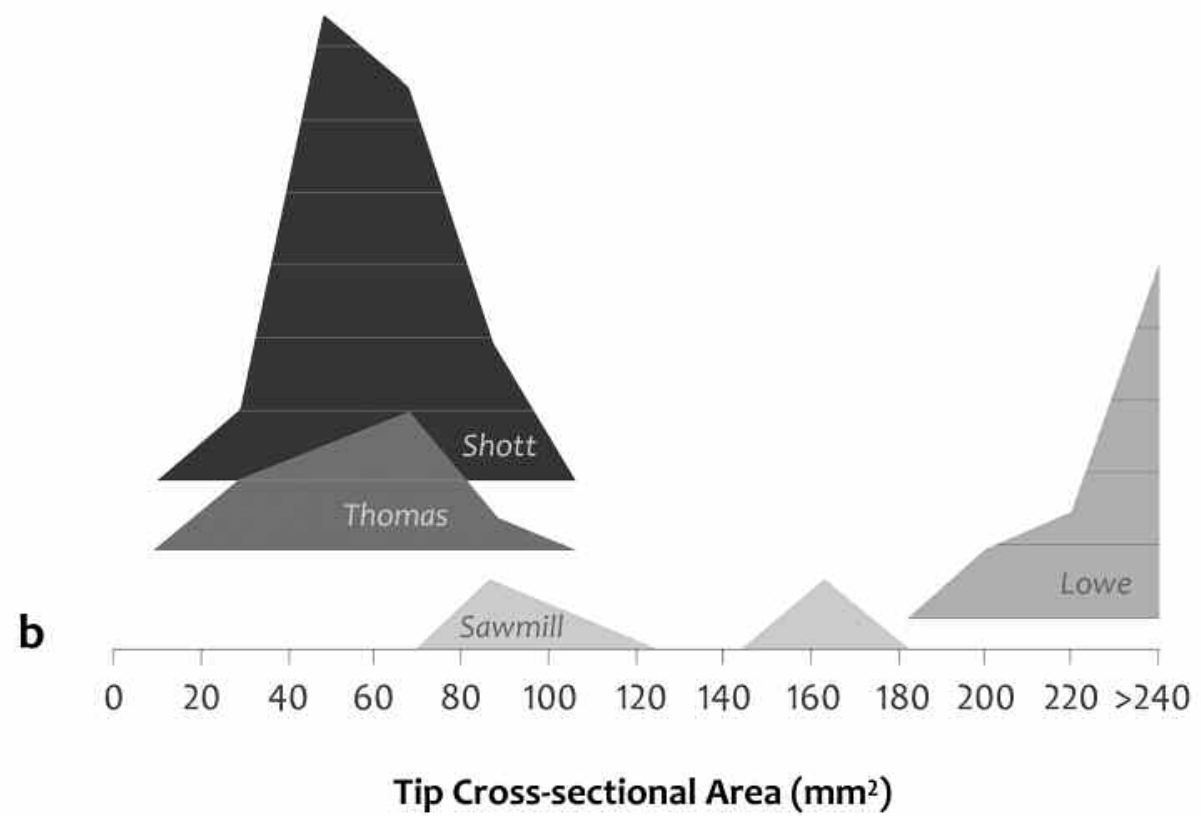

Figure 6. Absolute frequency distribution of Lowe, Sawmill, and archaeological and ethnographic dart points in Shott 1997 and Thomas 1978 by: (a) neck width $(\mathrm{mm})$ and (b) tip cross-sectional area $\left(\mathrm{mm}^{2}\right)$. Note that individual curves are unstacked and that the gridlines represent increments of 2 in absolute frequency (charts by C. Helmke and W. J. Stemp).

(length, width, thickness, and neck width), Shott's (1997) and Thomas's (1978) data were combined to establish 95 percent confidence intervals (CI) around sample means using standard deviation calculated for each of these four dimensions.

$$
\mathrm{CI}=\overline{\mathrm{X}} \pm 1.96(\mathrm{~s})
$$

The CI ranges were then used to determine whether individual Lowe and Sawmill points could be identified as spear-thrower dart points based on these four dimensions. Results (Table 2) indicate that 19 Lowe points fell into the CI range for only one dimension based on comparisons with the combined data from Shott (1997) and Thomas (1978). In contrast, most (88.9 percent) of the 18 Sawmill points were within the CI ranges for two or more dimensions using the same 
comparative data. These calculations indicate that Sawmill points could have been dart points, but Lowe points most likely were not.

\section{Tip Cross-Sectional Area (TCSA)}

The tip cross-sectional area (TCSA) of a point has been used to argue that some stone artifacts were likely used as projectiles of different types (i.e., arrow, spear-thrower dart, throwing spear) based on "the force necessary to penetrate a target to a lethal depth" (Sisk and Shea 2011:2). TCSA of a bifacial point with a rhomboidal cross-section is calculated by multiplying half of its maximum width by its maximum thickness (Hughes 1998:354, Table II; Sisk and Shea 2011:3, Figure 1). Comparisons of the TCSAs from points in Shea (2006:825, Table 1) with those for Lowe and Sawmill points suggest that both of these bifaces types are too wide and thick to have served as effective dart points (Table 1, Figure 6b). Moreover, Hughes's (1998:356, Table IV) estimated threshold values for TCSAs for thrusting spears $\left(310 \mathrm{~mm}^{2}\right)$, flight spears $\left(210 \mathrm{~mm}^{2}\right)$, and dart points $\left(67 \mathrm{~mm}^{2}\right)$ indicate that Lowe and Sawmill points would not have been effective dart points. Nevertheless, 87.5 percent $(N=14)$ of the Lowe points would have made serviceable thrusting spears, and 80 percent $(N=4)$ of the Sawmill points would have been effective throwing spears based on these thresholds. The analysis of stone projectile points and knives from Australia by Newman and Moore (2013) demonstrates that some aboriginal peoples designed tools that did not place significant emphasis on TCSA. Ames et al. (2010:298) also calculated that TCSA correctly identified only 73 percent of Thomas's (1978) and Shott's (1997) dart points.

\section{Preceramic Biface Function: Macrowear and Microwear}

The possible functions of the Lowe and Sawmill points were also investigated based on use-wear, but a number of factors limited this analysis. Specifically, a more detailed program of use-wear analysis was hampered by the fact that a significant number of points held in private collections were not accessible for examination. Macrowear and microwear analyses were also limited to a small number of artifacts because the majority were recovered as surface finds. As a result, they are heavily patinated and were subject to multiple post-depositional alterations.

Despite these issues, 27 points were examined for macrowear evidence that could indicate use as projectiles (Dockall 1997; Fischer et al. 1984; Odell and Cowan 1986; Titmus and Woods 1986), and five points were examined for microwear, specifically striations and microscopic linear impact traces [MLITs] (Fischer et al. 1984). A 10x hand lens and a 10x-40x digital microscope [eScope] were used to document the presence of longitudinal macrofractures (bending, snap, cone, and "spin-off" fractures of the tip), lateral macrofractures ("burin-like" fractures of the tip), distal/transverse fractures, distal end crushing, neck bending fractures, and barb shear fractures. The digital microscope was also used to locate and identify wear traces at 200x magnification.

Macrowear analysis indicated that seven (35.0 percent) of 20 Lowe points and two (28.9 percent) of seven Sawmill points retained evidence consistent with their use as projectiles. On the Lowe points, macrowear was represented by longitudinal fractures on the distal ends of five points (Figures 2c, d, 4b, c, 7a), a transverse fracture on one point (Figure 2b), and a lateral fracture on another (Figure $2 \mathrm{k}$ ). The bending fracture on the distal end of the $\mathrm{JuaD} / 98 / 12 / 4$ point (Figure $7 \mathrm{~b}$ ) is also associated with a rotary motion break. Whether this was due to the impact of a spinning projectile with its target cannot be determined. Use-related damage on the Sawmill points included a neck bending fracture (Figure $3 \mathrm{c}$ ) and a barb shear fracture; no damage was observed on the distal ends of the artifacts, most likely due to resharpening.

Some fractures were discounted as resulting from projectile impact based on the difference in stone coloration of the flake scar(s) resulting from impact and the surrounding patinated tool surface. For example, we concluded that the tip fracture on the point from Actun Tzimin (Lohse 2010:326, Figure 6D) resulted from damage sustained postpatination. This approach was also used to discount the shear barb fractures on three Lowe points. Although we attributed the distal/transverse fracture on the JuaD98/12/2 point to projectile impact, use-wear analysts have cautioned that these types of fractures may also be the product of manufacture, accidental breakage, or other uses 


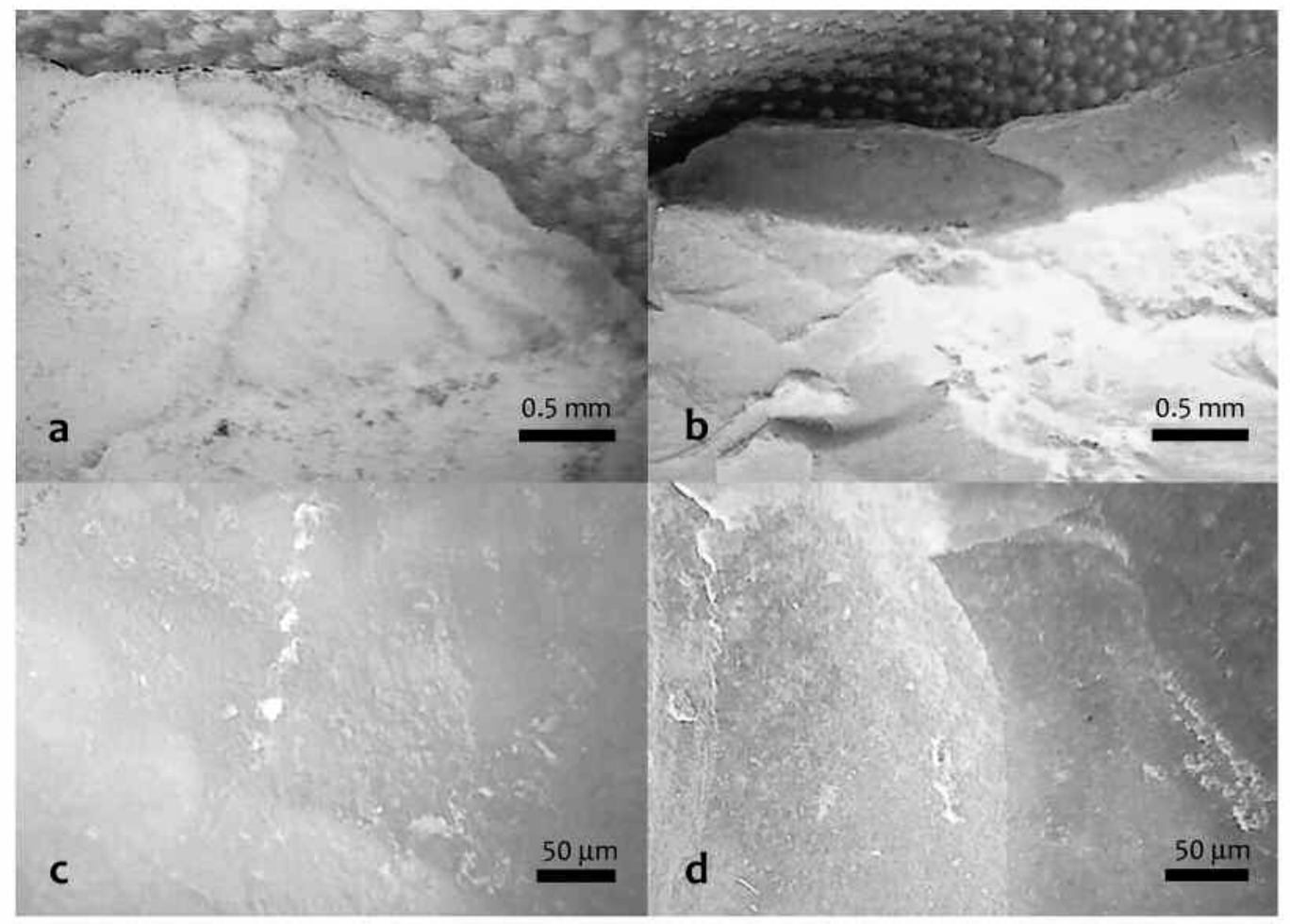

Figure 7. Photomicrographs of projectile damage: (a) step terminating bending fracture on the tip of PNK360 Lowe point; (b) bending fracture with "twisting" on tip of JuaD98/12/4 Lowe point; (c) Linear polish (MLIT) just below the break on the Billy White Lowe point; (d) Lowe point from Caves Branch Rockshelter - weak linear polish (left side) and bone polish (right side) (photomicrographs by K. Prufer and W. J. Stemp).

(Ahler 1971:58; Dockall 1997:326). In some instances, such as the Lowe point from San Ignacio (Iceland 1997:192, Figure 4.4b) and another from Lowe Ranch (Hester et al. 1980b:19, Figure 1), tool repair may have removed evidence of transverse breaks to the blades of the point.

Microwear evidence consistent with projectile use was recorded on two of five (40 percent) of the least patinated Lowe points. The Billy White point (Figure $7 \mathrm{c}$ ) retained a microscopic linear impact trace (MLIT) below the distal end fracture. The Caves Branch Rockshelter point had both weak linear polish below the distal tip break and micropolish consistent with contact with bone (Figure $7 \mathrm{~d}$ ). Whether bone contact was due to projectile use or butchery using the point as a knife cannot be determined based on available evidence. Distinguishing spear points from dart points based on this limited macrowear and microwear dataset was not possible. Nevertheless, we believe tha there is sufficient evidence to sug- gest the use of some Lowe and Sawmill points as projectiles.

\section{Preceramic Biface Function: Design Features}

The functions of these preceramic bifaces can also be approached from the perspective of design features, specifically large barbs, alternate-opposite edge beveling, and edge serration.

\section{Barbs}

Barbs are common features on projectile points, but not all projectile points will necessarily have barbs (Newman and Moore 2013). Barbs prevent points from becoming dislodged from their targets (Cundy 1989:36; Flenniken and Wilke 1989:151). Because thrusting spears are designed to be easily withdrawn from the target to allow additional thrusts, they generally do not have barbs (Hughes1998:358). Thrusting spears could have barbed points if the foreshaft was detachable and 
Table 2. Number of Lowe and Sawmill Points above the 95\% Confidence Intervals (CI) around the Mean using Standard Deviation Calculated for the Point Dimensions (Length, Width, Thickness, and Neck Width) based on Dart Point Data from Thomas (1978) and Shott (1997).

\begin{tabular}{lcccc}
\hline Point Type (N) & Four dimensions $^{\mathrm{a}}$ & Three dimensions $^{\mathrm{b}}$ & Two dimensions $^{\mathrm{c}}$ & One dimension $^{\mathrm{d}}$ \\
\hline Lowe (42) & 0 & 0 & 0 & 19 \\
Sawmill (18) & 1 & 4 & 9 & 2 \\
\hline
\end{tabular}

a95\% CI for length - 20.4-82.62 mm

b95\% CI for width $-11.87-33.74 \mathrm{~mm}$

${ }^{\mathrm{c}} 95 \% \mathrm{CI}$ for thickness $-2.5-7.43 \mathrm{~mm}$

d $95 \%$ CI for neck width - 7.31-22.96 mm

would stay embedded in the animal (see Sullivan [1980] for repeating lances). In the absence of a repeating lance, barbs would seem to argue against the use of Lowe and Sawmill points as stabbing/thrusting tools. Nevertheless, the barbing of points would be advantageous for hunting aquatic prey. Throughout coastal locations in the Americas there are numerous examples of stone and bone or ivory points with large rear-facing barbs used as harpoons to hunt sea mammals and fish (Mason 1902). Relatedly, long (130 mm) metal harpoon heads were made by the Siona of Amazonian Ecuador for hunting manatee, large freshwater fish, and caiman (Timm et al. 1989:2, Figure 1).

Chipped stone knives with their original handles still intact were not usually barbed (Hester 1970; Sollberger 1971; Willoughby 1902). In North America, however, some barbed bifaces without handles were classified as knives based on usewear analyses. Thebes points, which are commonly beveled and have barbs, are often considered knives based on the lack of damage associated with impact (White 2013:85). The barbs are outflaring, and these points also possess wide stems that are generally the same width as the barbs (O'Brien and Wood 1998:134, Figure 3.28; White 2013:81, Figure 2) unlike Lowe and Sawmill points.

\section{Alternate-Opposite Edge Beveling and Edge Serration}

Alternate-opposite edge beveling has been interpreted as evidence of stone tool resharpening (Sollberger 1971). This resharpening technique would have conserved raw material and extended the use-life of a maintainable tool (Bleed 1986). Stone points were frequently rejuvenated while still hafted because retouching the point in the haft is much more time and energy efficient than removing and rehafting it (Frison 1978:125; Morse 1971).

Preceramic points from Belize may have been used as knives based on their serrated edges and the beveling of alternate-opposite tool edges due to resharpening (see Bradley 1997; Flenniken and Wilke 1989; Goodyear 1974, 1982:391; Sollberger 1971). The interpretation of beveled and serrated bifaces as knives is primarily based on use-wear analysis of North American bifaces, such as Dalton, Thebes, and Hardin points (Justice 1995:5156). Given the presence of wear associated with cutting or slicing of soft substances, such as meat or hide (Ahler 1971; Michie 1973; Yerkes and Gaertner 1997), Dalton points have been interpreted as knives. Nevertheless, this kind of beveling is not exclusive to stone tools used as knives. Resharpening of only one side of each edge may have been done for other reasons. Points may have been beveled on alternate-opposite edges to affect the aerodynamics of flight, specifically stability and rotation. There is evidence supporting the rotation and stability hypotheses for beveled points on short, straight shafts used in a wind tunnel (see Lipo et al. 2012). In contrast, Pettigrew et al. (2015:597) concluded that there was no relationship between beveled points and direction of rotation for longer projectiles with flexible shafts based on their experiments using beveled and unbeveled points on spear-thrower darts. They also demonstrate that stabilization due to alternate beveling seems unlikely, given the variation observed between throws. Additionally, Pettigrew et al. (2015:599) tested whether alternate-opposite edge beveling would rotate a point upon impact with its target, thus creating a more severe wound. Although their results are inconclusive, they did observe that beveled dart points can turn in a car- 
cass. It may be that hunters beveled and serrated their stone dart points because they believed that doing so would increase their lethalness.

\section{Discussion}

If there was no projectile technology in the Preceramic period of Belize, hunters would have been limited to certain close-quarter hunting tactics, possibly involving disadvantage or ambush techniques (Churchill 1993:17; Rasic and Slobodina 2008:82). In terms of the types of prey available to Archaic-period hunters in Belize, there are limited faunal data from this period. Pohl et al. (1996:363-364) "found the remains of freshwater fish (Cichlasoma sp., Ictalurus sp., Synbranchus sp.), snakes (Colubridae), small mammals such as armadillo (Dasypus novemcinctus), and especially turtles (Staurotypus sp.)" in association with the Lowe point from Pulltrouser Swamp in northern Belize. Lohse (2010:323, Table 1) recovered the remains of common agouti (Dasyprocta), armadillo, snakes, and possibly white-tailed deer (Artiodactyl) from Late Archaic contexts in Actun Halal in Western Belize. This evidence suggests a diet that included both aquatic and terrestrial animals of various types and sizes, in addition to plant foods (see Iceland and Hester 2001:293; Pohl et al. 1996).

Based on the limited use-wear analysis for the Lowe and Sawmill points, it can be argued that some of these bifaces served as projectile points. Metric data suggest that they were designed to serve different functions (Rasic and Slobodina 2008; White 2013:74-75 for function vs. style). Because the neck widths of Lowe and Sawmill points are significantly different, each type was designed to fit into a handle/shaft of different diameters. Based on neck widths, Lowe points seem to have been designed as heavy armatures slotted into thicker handles or shafts/foreshafts. Their TCSAs indicate their use as thrusting spears. Although the large barbs would seem to contradict this, Lowe points may have made effective harpoons by preventing aquatic prey from slipping from the point. The Sawmill points seem better designed as dart points, given their neck widths and the $45-85 \mathrm{~cm}$ range of length measurements. Moreover, confidence intervals (CI) calculated based on the four dimensions from the Sawmill points support their likely use on spear-thrower darts. Yet the limited number of TCSAs calculated for the Sawmill points do not support this proposed function.

Both point types also likely made serviceable knives. This could be accomplished if the foreshaft was removed and held in the hand as a hafted knife (Rasic and Slobodina 2008:79). Not only would the wider shoulders of the preceramic points provide broader blades for opening larger wounds when used as projectiles (Flenniken and Wilke 1989:151), they would produce long serrated edges for cutting and sawing (Goodyear 1974; Rasic and Slobodina 2008). Using Sawmill and Lowe points as both projectile points and knives would have minimized the need for additional formal tools in the toolkits of preceramic peoples who inhabited Belize. Because metric data suggest that Lowe and Sawmill points represent two different types of tools, this might indicate different strategies or prey for those hunters who used one or the other (see Churchill 1993; Ellis 1997; Hrdlicka 2003; Hughes 1998; Shott 1993; Whittaker 2010 for speed, thrust/force upon impact, range, hide thickness/penetration depth, wound size, and environments). It is also possible that Lowe points hafted onto thrusting/throwing spears or harpoons were used in conjunction with Sawmill dart points to finish off wounded prey (Hughes 1998:395; Rasic and Slobodina 2008:82; see Cundy 1989; Ellis 1997).

Geographically, Lowe and Sawmill points are quite widely distributed and overlap significantly in northern, central, and western Belize. Based on the locations where Lowe and Sawmill points have been found, it seems unlikely that these point types can be used as ethnic markers for culturally distinct preceramic populations that exclusively inhabited different parts of Belize. The suggestion that any one group of hunter-gatherers identified by point type was culturally connected to the earliest regional Maya pottery traditions, such as $\mathrm{Cu}$ nil and Swazey (Awe 1992:344-350; Clark and Cheetham 2002:306), is not supported (see Lohse 2010:315-318, 342; Rosenswig 2015:138). The chert assemblages associated with the earliest ceramics in western Belize and eastern Guatemala, for example, consist of core and flake technology and do not demonstrate any evidence of biface production (Aoyama 2010; Aoyama and Munson 
2012; Stemp 2012; Yacubic 2006). Moreover, Iceland (1997; Lohse et al. 2006:222) noted a hiatus in the artifact record in northern Belize between roughly 1900-1300 B.C. This divides the lithic technology of the Late Archaic into the Early Preceramic facet (3400-1900 B.C.), to which Lowe points are currently assigned, and the Late Preceramic facet (1500-900 B.C.). Even if the 2500 1900 B.C. dates for Lowe points are accepted as applying to all stemmed and barbed point types, conventional glottochronology suggests that the speakers of proto-Maya lived sometime between 4000 and 3500 B.P. (Brown and Wichmann 2004; Kaufman 1976). Alternate models stipulate the dates around 6500 to 6000 B.P. for the branching of Wastek from proto-Mayan (Atkinson 2006), and more recent proposals push the dates to the other extreme, to 2200 B.P. using automated lexical comparisons (Holman et al. 2011). As such, any substantiation of cultural continuities that extended from the Early Preceramic facet of the Late Archaic into the earliest Maya times necessitates a more detailed chronological framework for the preceramic points in relation to other lithic technology, material culture, and linguistics.

\section{Conclusions}

A multitude of factors, climatic and environmental among them (Rosenswig 2015), likely contributed to a longer reliance on mobile hunting and gathering for preceramic peoples in Belize than for those living in other regions in Mesoamerica where more permanent sedentism and food-production developed earlier (e.g., Blake et al. 1995; Cheetham and Clark 2002; Iceland and Hester 2001; Lohse 2010; MacNeish and Nelken-Terner 1983a; Rosenswig 2006a, 2006b, 2015; Zeitlin and Zeitlin 2000). There is still much we do not know about the preceramic people who lived in Belize; diligent work and fortuitous finds have increased our knowledge of this time period and provided a better sense of how its inhabitants designed and used their stone tools. For hunting and gathering populations, the need for reliable hunting tools was paramount. Tools likely also had to be maintained with relative ease, and using a tool for more than one purpose as need arose would place a premium on portable, multi-purpose ones (Bleed 1986).
If Sawmill points were dart points and knives, whereas the larger Lowe points were affixed to thrusting/throwing spears or harpoons and were also used as knives, this may account for overlap in their regional distributions. Because of the large barbs on both types of points, these tools may have been used to hunt aquatic mammals, reptiles, and fish. Spears and darts may not necessarily have been used for the same prey. Whether these two biface types were contemporaneous cannot be known based on the limited dating evidence. The early example of beveling from southern Belize raises the possibility that tools with beveling on alternate-opposite edges are older in this part of the world than the Late Archaic period requiring revision of the current preceramic chronology (e.g., Lohse et al. 2006:222, Figure 8).

Acknowledgments. Preceramic point data and photographs were made available thanks to the hard work and generosity of many people. In particular, the authors would like to thank Rob Rosenswig (SUNY-Albany) and several Belizeans who shared their individual finds or collections with us. The authors also extend their gratitude to Carolyn Keller, Department of Sociology, Anthropology, and Criminology, Keene State College, who ran the CI analysis. Research in Belize has been conducted under the auspices of the Belize Institute of Archaeology (IOA). At the IOA, we are particularly grateful for the assistance of Dr. John Morris, Dr. Allan Moore, Rafael Guerra, Melissa Badillo, and Antonio Beardall. This work was made possible through a Keene State College Faculty Development Grant awarded to W. J. Stemp, by a Social Science Research Council of Canada Grant and Tilden Family Foundation Grants to Jaime Awe, and funding from the Alphawood Foundation provided to K. Prufer. We would like to thank the editor, Geoffrey Braswell, and John Clark and the five anonymous reviewers for their insightful and helpful comments.

Data Availability Statement. The lists of known Lowe, Sawmill, Allspice, and Ya'axche' points from Belize used in this study are published online in Supplemental Tables 1-4.

Supplemental Materials. Supplemental materials are linked to the online version of this article, which is accessible via the SAA member login at www.saa.org/.

Supplemental Table 1. Lowe Points from Belize.

Supplemental Table 2. Sawmill Points from Belize.

Supplemental Table 3. Allspice (Provisional) Points from Belize.

Supplemental Table 4. Ya'axche' (Provisional) Points from Belize. 


\section{References Cited}

Ahler, Stanley A.

1971 Projectile Point Form and Function at Rodgers Shelter, Missouri. Missouri Archaeological Society Research Series 8, edited by W.R. Wood, Missouri Archaeological Society and the University of Missouri-Columbia, Columbia.

Ames, Kenneth M., Kristen A. Fuld, and Sara Davis 2010 Dart and Arrow Points on the Columbia Plateau of Western North America. American Antiquity 75:287-325.

Aoyama, Kazuo

2010 Los artefactos litícos y la organización socioeconómica del Preclásico en Ceibal. In XXIII Simposio de Investigaciones Arqueológicas en Guatemala, 2009, edited by Barbara Arroyo, Adriana Linares, and Lorena Paiz, pp. 956-963. Museo Nacional de Arqueología y Etnología, Guatemala.

Aoyama, Kazuo, and Jessica Munson

2012 Ancient Maya Obsidian Exchange and Chipped Stone Production at Caobal, Guatemala. Mexicon 34:34 42.

Atkinson, Quentin

2006 From Species to Languages: A Phylogenetic Approach to Human Prehistory. Unpublished Ph.D. thesis, Department of Psychology, University of Auckland, Auckland, New Zealand.

Awe, Jaime J.

1992 Dawn in the Land between the Rivers: Formative Occupation at Cahal Pech, Belize and its Implication for Preclassic Developments in the Maya Lowlands. Unpublished Ph.D. dissertation, Institute of Archaeology, University of London, England.

Aylesworth, Grant R., Brent D. Suttie, Bruce Templeton, Ashley Brzezicki, William J. Webb, and A. William McGrath

2011 Preliminary Report on the 2010 Activities of the Mount Allison University Archaeological Field School in Belize. In Research Reports from the Programme for Belize Archaeological Project, Vol. 5, edited by Brett A. Houk and Fred Valdez, Jr., pp. 229-233. Mesoamerican Archaeological Research Laboratory, Occasional Papers, No. 12, University of Texas at Austin, Austin.

Blake, Michael, John E. Clark, Barbara Voorhies, George Michaels, Michael W. Love, Mary E. Pye, Arthur A. Demarest, and Barbara Arroyo

1995 Radiocarbon Chronology for the Late Archaic and Formative Periods on the

Pacific Coast of Southeastern Mesoamerica. Ancient Mesoamerica 6:161-183.

Bleed_Peter

1986 The Optimal Design of Hunting Weapons: Maintainability or Reliability. American Antiquity 51:737747.

Bradley,Bruce A.

1997 Sloan Site Biface and Projectile Point Technology. In Sloan: A Paleoindian Dalton Cemetery in Arkansas, edited by D. F. Morse, pp. 53-57. Smithsonian Institution Press, Washington, D.C.

Brown, Cecil H., and Søren Wichmann

2004 Proto-Mayan Syllable Nuclei. International Journal of American Linguistics 70(2):128-186.

Brown, Kenneth L.

1980 A Brief Report on Paleoindian-Archaic Occupation in the Quiche Basin, Guatemala. American Antiquity 45:313-324.
Churchill, Steven E.

1993 Weapon Technology, Prey Size Selection, and Hunting Methods in Modern Hunter-Gatherers: Implications for Hunting in the Palaeolithic and Mesolithic. Archeological Papers of the American Anthropological Association 4:11-24.

Clark, John E., and David Cheetham

2002 Mesoamerica's Tribal Foundations. In The Archaeology of Tribal Societies, edited by W. A. Parkinson, pp. 278339. International Monographs in Prehistory, Archaeological Series 15, University of Michigan, Ann Arbor.

Corliss, David W.

1972 Neck Width of Projectile Points: An Index of Culture Continuity and Change. Occasional Papers of the Idaho State University Museum 29, Idaho State University, Pocatello.

Cundy, B. J.

1989 Formal Variation in Australian Spear and Spearthrower Technology. British Archaeological Reports, International Series 546, Oxford.

Dockall, John E.

1997 Wear Traces and Projectile Impact: A Review of the Experimental and Archaeological Evidence Journal of Field Archaeology 24:321-331.

Ellis, Christopher J.

1997 Factors Influencing the Use of Stone Projectile Tips: An Ethnographic Perspective. In Projectile Technology, edited by $\mathrm{H}$. Knecht, pp. 37-74. Plenum Press, New York.

Faugère, Brigitte

2006 Cueva de los Portales: un sitio arcaico del Norte de Michoacán, México. Instituto Nacional de Antropología e Historia, Série Arqueología 494, México.

Fischer Anders, Peter V. Hansen, and Peter Rasmussen 1984 Macro and Micro Wear Traces on Lithic Projectile Points: Experimental Results and Prehistoric Examples. Journal of Danish Archaeology 3:19-46.

Flannery, Kent V.

1986 Guila Naquitz: Archaic Foraging and Early Agriculture in Oaxaca, Mexico. Academic Press, Orlando.

Flannery, Kent V., and Ronald Spores

1983 Excavated Sites of the Oaxaca Preceramic. In The Cloud People: Divergent Evolution of the Zapotec and Mixtec Civilizations, edited by Kent V. Flannery and Joyce Marcus, pp. 20-26. Percheron Press, Clinton Corners.

Flenniken, J. Jeffrey, and Philip J. Wilke

1989 Typology, Technology, and Chronology of Great Basin Dart Points. American Anthropologist 91:149-158.

Frison, George C.

1978 Prehistoric Hunters of the High Plains. Academic Press, New York.

1989 Experimental Use of Clovis Weaponry and Tools on African Elephants. American Antiquity 54:766-784.

Goodyear, Albert C. 1974 The Brand Site: A Techno-functional Study of a Dalton Site in Northeast Arkansas. Research Series No. 7, Arkansas Archaeological Survey, Fayetteville.

1982 The Chronological Position of the Dalton Horizon in the Southeastern United States. American Antiquity 47:382-395.

Gramly, Richard M

1984 Kill Sites, Killing Ground and Fluted Points at the Vail Site. Archaeology of Eastern North America 12:110 121.

Gruhn, Ruth, and Alan Bryan

1977 Los Tapiales, A Paleo-Indian Campsite in the 
Guatemalan Highlands. Proceedings of the American Philosophical Society 121:235-273.

Hardy, Karen

1996 The Preceramic Sequence from the Tehuacan Valley: A Re-evaluation. Current Anthropology 37:700-716.

Helmke, Christophe G.B., and Reiko Ishihara

2001 Archaeological Reconnaissance of Cueva Migdalia, Barton Creek Valley, Cayo District, Belize. The Belize Valley Archaeological Reconnaissance Project 7(1):111151.

Hester, Thomas R.

1970 A Study of Wear Patterns on Hafted and Unhafted Bifaces from Two Nevada Caves. In Contributions of the University of California Archaeological Research Facility No. 7, pp. 44-54. University of California, Berkeley.

1985 The Maya Lithic Sequence in Northern Belize. In Stone Tool Analysis: Essays in Honor of Don E. Crabtree, edited by Mark G. Plew, James C. Woods, and Max G. Pavesic, pp. 187-210, University of New Mexico Press, Albuquerque.

1986 On the Misuse of Projectile Point Typology in Mesoamerica. American Antiquity 51:412-414.

Hester, Thomas R., Harry B. Iceland, Dale B. Hudler, and Harry J. Shafer

1996 The Colha Preceramic Project: Preliminary Results from the 1993-1995 Field Seasons. Mexicon 18:45-50.

1995 The Colha Preceramic Project: A Status Report. Texas Papers on Latin America, No. 95-03, Teresa Lozano Long Institute of Latin American Studies, University of Texas at Austin, Austin.

Hester, Thomas R., Thomas C. Kelly, and Giancarlo Ligabue 1981 A Fluted Paleo-Indian Projectile Point from Belize, Central America. Working Papers in Archaeology No. 1, Center for Archaeological Research, University of Texas at San Antonio, San Antonio.

Hester, Thomas R., Harry J. Shafer, and Thomas C. Kelly 1980a A Preliminary Note on Artifacts from Lowe Ranch: A Preceramic Site in Belize. In The Colha Project Second Season: 1980 Interim Report, edited by Thomas R. Hester, Jack Eaton and Harry J. Shafer, pp. 229-232. University of Texas at San Antonio and Centro Studi e Ricerche Ligabue, Venice.

1980b Lithics from a Preceramic Site in Belize: A Preliminary Note. Lithic Technology 9:9-10.

Hole, Frank

1986 Chipped Stone Tools. In Guila Naquitz: Archaic Foraging and Early Agriculture in Oaxaca, Mexico, edited by Kent Flannery, pp. 97-139. Academic Press, Orlando.

Holman, Eric. W., Cecil. H. Brown, Søren Wichmann, André Müller, Viveka Velupillai, Harald Hammarström, Sebastian Sauppe, Hagen Jung, Dik Bakker, Pamela Brown, Oleg Belyaev, Matthias Urban, Robert Mailhammer, JohannMattis List, and Dmitry Egorov

2011 Automated Dating of the World's Language Families Based on Lexical Similarity. Current Anthropology 52:841875.

Hrdlicka, Daryl

2003 How Hard Does It Hit? A Revised Study of Atlatl and Dart Ballistics. The Atlatl

16(2):15-18.

Huckell, Bruce B.

1982 The Denver Elephant Project: A Report on Experimentation with Thrusting Spears. Plains Anthropologist 27:217-224.

Hughes, Susan S.

1998 Getting to the Point: Evolutionary Change in Prehistoric
Weaponry. Journal of Archaeological Method and Theory 5:345-403.

Hutchings, W. Karl

1997 The Paleoindian Fluted Point: Dart or Spear Armature? The Identification of Paleoindian Delivery Technology through the Analysis of Lithic Fracture Velocity. Ph.D. dissertation, Department of Archaeology, Simon Fraser University, Vancouver.

Iceland, Harry B.

1997 The Preceramic Origins of the Maya: The Results of the Colha Preceramic Project in Northern Belize. Unpublished Ph.D. dissertation, Department of Anthropology. University of Texas at Austin, Austin.

2005 The Preceramic to Early Middle Formative Transition in Northern Belize: Evidence for the Ethnic Identity of the Preceramic Inhabitants. In New Perspectives on Formative Mesoamerican Cultures, edited by Terry G. Powis, pp. 15-26, British Archaeological Reports, International Series 1377, Oxford.

Iceland, Harry B., and Thomas R. Hester

2001 Lowland Mesoamerican Archaic. In Encyclopedia of Prehistory, Vol. 5, Middle America, edited by Peter N. Peregrine and Melvin Ember, pp. 292-302. Kluwer Academic, Nowell.

Justice, Noel D.

1995 Stone Age Spear and Arrow Points of the Midcontinental and Eastern United States: A Modern Survey and Reference. Indiana University Press, Bloomington.

Kaufman, Terrence

1976 Archaeological and Linguistic Correlations in Mayaland and Associated Areas of Meso-America. World Archaeology 8:101-118.

Kelly, Thomas C.

1993 Preceramic Projectile-Point Typology in Belize. Ancient Mesoamerica 4:205-227.

Lipo, Carl P., Robert C. Dunnell, Michael J. O'Brien, Veronica Harper, and John Dudgeon

2012 Beveled Projectile Points and Ballistics Technology. American Antiquity 77:774-788.

Lohse, Jon $\mathrm{C}$

2005 Preceramic Occupation in Belize. Research Reports in Belizean Archaeology 2:441-457.

2010 Archaic Origins of the Lowland Maya. Latin American Antiquity 21:312-352.

Lohse, Jon C, Jaime Awe, Cameron Griffith, Robert M. Rosenswig, and Fred Valdez Jr.

2006 Preceramic Occupations in Belize: Updating the Paleoindian and Archaic Record. Latin American Antiquity 17:209-226.

Lohse, Jon C., and Michael B. Collins

2004 Lithic Artifacts Recovered in Association with Pleistocene Fauna from Actun Halal Cave, Western Belize. Unpublished report on file with the Western Belize Regional Cave Project, Bloomington, and the Institute of Archaeology, Belmopan, Belize.

Lucero, Lisa J., Patricia A. Beddows, and Andrew Kinkella

2011 Diving the Sacred Pools of Cara Blanca, Belize. Research Reports in Belizean Archaeology 8:233-240.

McAnany, Patricia A.

2010 Ancestral Maya Economies in Archaeological Perspective. Cambridge University Press, Cambridge.

McAnany, Patricia A., Satoru Murata, Ben S. Thomas, Sandra L. López Varela, Daniela Finamore, and David G. Buck 2004 The Deep History of the Sibun River Valley. Research Reports in Belizean Archaeology 1:295-310.

MacNeish, Richard S.

1981 Second Annual Report of the Belize Archaic Archae- 
ological Reconnaissance. R. S. Peabody Foundation for Archaeology, Andover.

1982 Third Annual Report of the Belize Archaic Archaeological Reconnaissance. R. S. Peabody Foundation for Archaeology, Andover.

1983 Mesoamerica. In Early Man in the New World, edited by Richard Shutler Jr., pp. 125-135. Sage, Beverly Hills.

MacNeish, Richard S., and Antoinette Nelken-Terner

1983a The Preceramic of Mesoamerica. Journal of Field Archaeology 10:71-84.

1983b Final Annual Report of the Belize Archaic Archaeological Reconnaissance. R. S. Peabody Foundation for Archaeology, Andover.

MacNeish, Richard S., Antoinette Nelken-Turner, and Irmgard W. Johnson

1967 The Prehistory of the Tehuacán Valley, Volume II: The Nonceramic Artifacts. University of Texas Press, Austin.

MacNeish, Richard S., Jeffery K. Wilkerson, and Antoinette Nelken-Terner

1980 First Annual Report of the Belize Archaic Archaeological Reconnaissance. R. S. Peabody Foundation for Archaeology, Andover.

Mason, Otis T

1902 Aboriginal American Harpoons: A Study in Ethnic Distribution and Invention. Smithsonian Institution, United States National Museum, Washington, D.C.

Michie, James L.

1973 A Functional Interpretation of the Dalton Projectile Point in South Carolina. South Carolina Antiquities 5:24 36.

Morse, Dan F.

1971 The Hawkins Cache: A Significant Dalton Find in Northeast Arkansas. The Arkansas Archeologist 12:9-20.

Newman, Kim, and Mark W. Moore

2013 Ballistically Anomalous Stone Projectile Points in Australia. Journal of Archaeological Science 40:2614 2620.

O'Brien, Michael J., and W. Raymond Wood

1998 The Prehistory of Missouri. University of Missouri Press, Columbia.

Odell, George H., and Frank Cowan

1986 Experiments with Spears and Arrows on Animal Targets. Journal of Field Archaeology 13:195-212.

Pearson, Georges A and Pete Bostrom

1998 A New Fluted Stemmed Point from Belize and Its Implications for a Circum-Caribbean Paleoindian Culture Area. Current Research in the Pleistocene 15:55-57.

Perttula, Timothy K.

2009 Typological Labeling of Early Holocene Projectile Points. Proceedings of the National Academy of Science USA 106:73.

Pettigrew, Devin B., John C. Whittaker, Justin Garnett, and Patrick Hashman

2015 How Atlatl Darts Behave: Beveled Points and the Relevance of Controlled Experiments. American Antiquity 80:590-601.

Pohl,Mary D., Kevin O. Pope, John G. Jones, John S. Jacob, Dolores R. Piperno, Susan D. deFrance, David L. Lentz, John A. Gifford, Marie E. Danforth, and J. Kathryn Josserand

1996 Agriculture in the Maya Lowlands. Latin American Antiquity 7:355-372.

Ranere, Anthony J., Dolores R. Piperno, Irene Hoist. Ruth Dickau, and José Iriarte

2009 The Cultural and Chronological Context of Early
Holocene Maize and Squash Domestication in the Central Balsas River Valley, Mexico. Proceedings of the National Academy of Science USA 106:5014-5018.

Rasic, Jeffrey T., and Natalia S. Slobodina

2008 Weapon Systems and Assemblage Variability during the Northern Archaic Period in Northern Alaska. Arctic Anthropology 45:71-88.

Rosenswig, Robert M.

2004 The Late Archaic Occupation of Northern Belize: New Archaeological Excavation Data. Research Reports in Belizean Archaeology 1: 267-277.

2006a Sedentism and Food Production in Early Complex Societies of the Soconusco, Mexico. World Archaeology 38:329-354.

2006b Northern Belize and the Soconusco: A Comparison of the Late Archaic to Formative Transition. Research Reports in Belizean Archaeology 3:59-71.

2015 A Mosaic of Adaptation: The Archaeological Record for Mesoamerica's Archaic Period. Journal of Archaeological Research 23:115-162.

Rosenswig, Robert M., and Marilyn A. Masson

2001 Seven New Preceramic Sites Documented in Northern Belize. Mexicon 23:138-140.

Rosenswig, Robert M., Deborah M. Pearsall, Marilyn A. Masson, Brendan J. Culleton, and Douglas J. Kennett

2014 Archaic Period Settlement and Subsistence in the Maya Lowlands: New Starch Grain and Lithic Data from Freshwater Creek, Belize. Journal of Archaeological Science 41:308-321

Scheffler, Timothy E.

2008 El Gigante Rock Shelter, Honduras, Unpublished Ph. D. dissertation. Department of Anthropology, Pennsylvania State University, College Station.

Scheffler, Timothy E., Kenneth G. Hirth, and George Hasemann 2012 The El Gigante Rockshelter: Preliminary Observations on an Early to Late Holocene Occupation in Southern Honduras. Latin American Antiquity 23:597-610.

Shea, John J.

2006 The Origins of Lithic Projectile Technology: Evidence from Africa, the Levant, and Europe. Journal of Archaeological Science 33:823-846.

Shott, Michael J.

1993 Spears, Darts, and Arrows: Late Woodland Hunting Techniques in the Upper Ohio Valley. American Antiquity 58:425-443.

1997 Stones and Shafts Redux: The Metric Discrimination of Chipped-Stone Dart and Arrow Points. American Antiquity 62:86-101.

Sisk, Matthew L., and John J. Shea

2011 The African Origin of Complex Projectile Technology: An Analysis using Tip Cross-sectional Area and Perimeter. International Journal of Evolutionary Biology. 2011:1-8.

Sollberger, John B.

1971 A Technological Study of Beveled Knives. Plains Anthropologist 16:209-218.

Stemp, W. James

2012 Changes in Stone Tool Technology from the Late Archaic to the First Maya Communities in Western Belize. Paper presented at the 6th Annual Maya at the Playa Conference, Palm Coast, Florida.

Stemp, W. James, and Jaime J. Awe

2013 Possible Variation in the Late Archaic Period Bifaces in Belize: New Finds from the Cayo District of Western Belize. Lithic Technology 38:17-31.

Stemp, W. James, Jaime J. Awe, and Christophe G. B. Helmke 2016 A Possible Paleoindian/Early Archaic Point from 
Ladyville, Belize, Central America. PaleoAmerica 2:70 73.

Sullivan, David

1980 The Repeating Lance. Central States Archaeological Journal 27:79-81.

Thomas, David H.

1978 Arrowheads and Atlatl Darts: How the Stones Got the Shaft. American Antiquity 43:461-472.

Timm, Robert M., Luis Albuja V., and Barbra L. Clauson 1989 Siona Hunting Techniques for the Larger Aquatic Vertebrates in Amazonian Ecuador. Studies in Neotropical Fauna and Environment 24:1-7.

Titmus, Gene I , and James C.Woods

1986 An Experimental Study of Projectile Point Fracture Pattern. Journal of California and Great Basin Anthropology 8:37-49.

Turner, Ellen S., Thomas R. Hester, and Richard McReynolds 2011 Stone Artifacts of Texas Indians, 3rd ed. Taylor, New York.

Valdez, Jr., Fred, and Grant Aylesworth

2005 A Fluted Paleoindian Point and Other Chipped Stone Tools from August Pine Ridge, Belize. Mono y Conejo 3:35-39.

White, Andrew A.

2013 Functional and Stylistic Variability in Paleoindian and Early Archaic Projectile Points from Midcontinental North America. North American Archaeologist 34:71108.

Whittaker, John C.

2010 Weapon Trials: The Atlatl and Experiments in Hunting Technology. In Designing Experimental Research in Archaeology: Examining Technology through Production and Use, edited by Jeffrey R. Ferguson, pp. 195-224. University Press of Colorado, Boulder.

Willoughby, Charles C.

1902 Prehistoric Hafted Flint Knives. The American Naturalist 36:1-6.

Winter, Marcus

2007 Recent Archaeological Investigations of Preclassic Occupations in the Southern Isthmus of Tehuantepec. In Archaeology, Art, and Ethnogenesis in Mesoamerican
Prehistory: Papers in Honor of Gareth W. Lowe, edited by Lynneth S. Lowe and Mary E. Pye, pp. 193-208. New World Archaeological Foundation, Papers 68, Brigham Young University, Provo.

Wrobel, Gabriel D.

2008 Report on the Caves Branch Rockshelter Excavations: 2006 and 2007 Field Seasons. In The Belize Valley Archaeological Reconnaissance Project: A Report of the 2007 Field Season, edited by C. G. B. Helmke and J. J. Awe, pp. 1-19. Institute of Archaeology, National Institute of Culture and History, Belmopan.

Wrobel, Gabriel, James Tyler, and Jessica Hardy

2007 Rockshelter Excavations in the Caves Branch River Valley. Research Reports in Belizean Archaeology 4:187196.

Yacubic, Matthew P.

2006 The Chipped Stone Tool Industries of Blackman Eddy, Belize. Master's thesis, Department of Anthropology, Brigham Young University, Provo.

Yerkes, Richard W., and Linda M. Gaertner

1997 Microwear Analysis of Dalton Artifacts. In Sloan: A Paleoindian Dalton Cemetery in Arkansas, edited by Dan F. Morse, pp. 53-57. Smithsonian Institution Press, Washington, D.C.

Zeitlin, Robert N.

1984 A Summary Report on Three Seasons of Field Investigations into the Archaic Period Prehistory of Lowland Belize. American Anthropologist 86:358-369.

Zeitlin, Robert N, and_Judith Francis_Zeitlin

2000 The Paleoindian and Archaic cultures of Mesoamerica. In The Cambridge History of Native Peoples of the Americas, Volume II: Mesoamerica, edited by Richard E. W. Adams and Murdo J. Macleod, pp. 45-121. Cambridge University Press, Cambridge.

Submitted August 28, 2015; Revised December 22, 2015; Accepted June 15, 2016. 